A F R I C A N M I L I T A R Y S T U D I E S ・ Volume 3

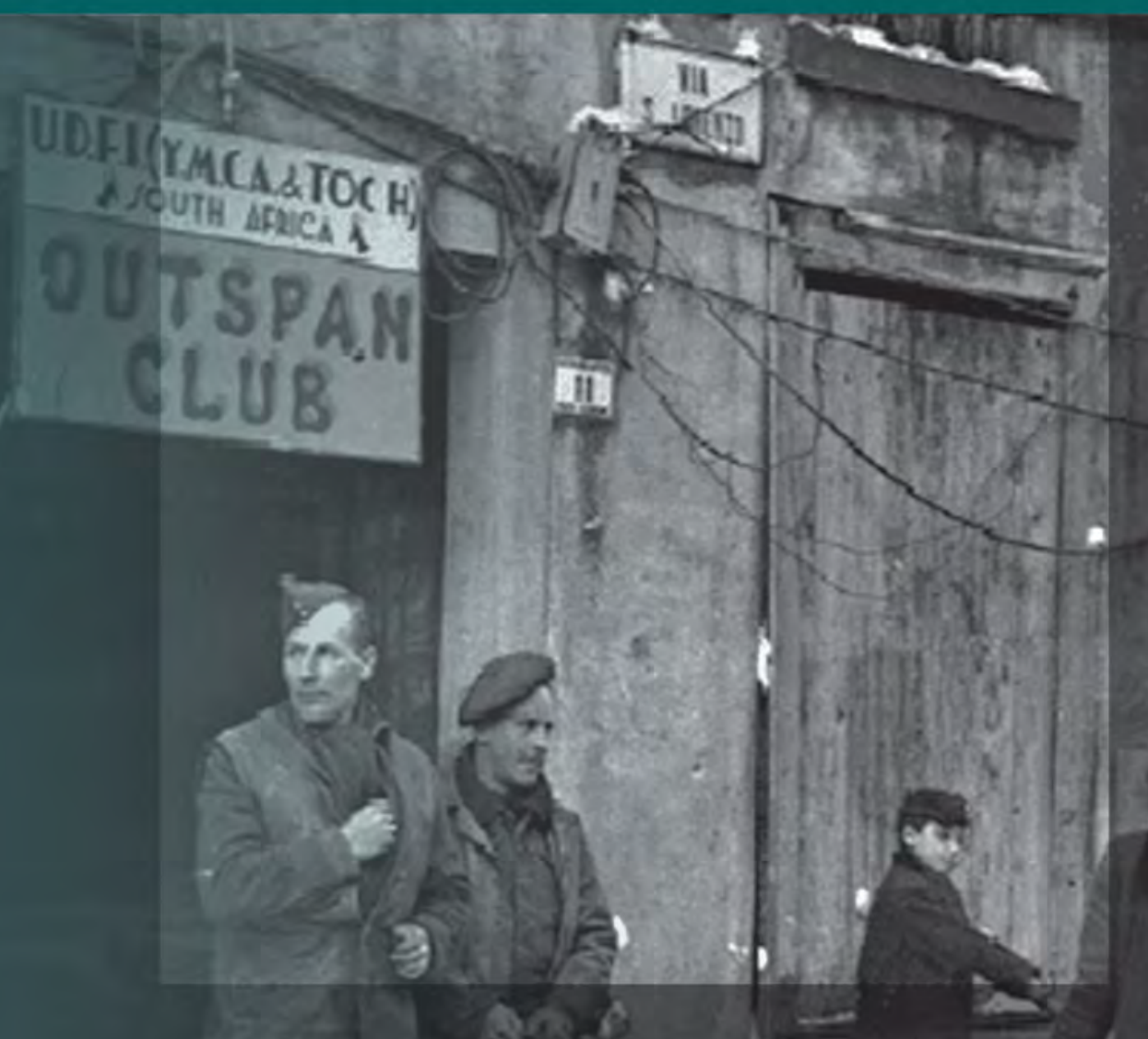

Sights, Sounds,

Memories

South African Soldier Experiences

of the Second World War 


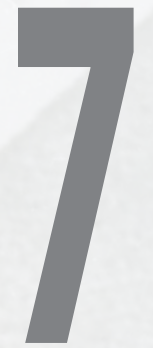

\section{'A HAPLESS POST OF HUNGRY MEN': INTERNED SOUTH AFRICAN COLOURED SOLDIERS IN EUROPE}

\section{Rishika Yadav}




\section{INTRODUCTION}

The Cape Corps, a non-combatant military unit, was part of South Africa's defence forces that were deployed during the Second World War. While initially it was only recruited from the 'Coloured' or 'mixed-race' community, this was later expanded to include the Indian and Malay Corps for logistical purposes. ${ }^{1}$ First established during the Great War as a combat unit, they were restricted to an auxiliary status in the Second World War and were subjected to a series of segregationist regulations. Despite these limitations, soldiers of the Cape Corps gave highly commendable service and were deployed in the North African, East African, Madagascar, the Middle East and Italian campaigns.

By 1941, the Cape Corps (CC), the Indian and Malay Corps (IMC), and the Native Military Corps (NMC) had been deployed in substantial numbers to North Africa. Inevitably, they were part of the South African forces (and Imperial forces) captured at Sidi Rezegh (1941) and during the fall of Tobruk (1942). ${ }^{2}$ While a considerable number of non-white POWs were kept in labour camps in North Africa to work on docks, a smaller portion of these soldiers were shipped across the Mediterranean to European camps where they served anywhere between two to four years in internment. This chapter examines the experience of the Cape Corps soldiers as prisoners of war in Europe.

Studies on POWs in the Second World War have seldom taken account of the experiences of non-white captives. One prominent example of this is the limited number of works on Japanese prisoners in internment camps. ${ }^{3}$ Most histories have detailed the plight of white Allied captives in Axis camps in Europe and beyond the continent, although this trend is now being reversed by recent scholarship. Still, the plight of South African soldiers and captives (including white servicemen) has been excluded from the overarching narratives on the Second World War. This 'shrinking history', as Bill Nasson notes, is a consequence of preoccupation of scholarship with the Anglo-Boer wars (or the South African wars), histories of apartheid, apartheid itself causing the scholarly seclusion of South Africa's role in the World Wars by academia in the West, and the lack of 'political capital' of South African participation resulting in these histories being cast aside in public memory. ${ }^{4}$ However, a small but assertive group of regional scholars has produced works of note on South Africa's role in the Second World War, but the story of its non-white captives remains wanting. ${ }^{5}$

This chapter focuses on a niche narrative within histories of war and captivity and asserts that the history of Coloured South African prisoners of war is unique and multifaceted. ${ }^{6}$ For the study of this history, it is important to understand three basic features from the outset. Firstly, CC soldiers were neither white nor commissioned. 
This fundamental difference in ethnicity and rank alone resulted in the creation of dissimilar experiences for CC POWs. Secondly, unlike a large proportion of nonwhite soldiers from the Empire who had been coerced into joining its defence, ${ }^{7}$ the non-white soldiers of South Africa had volunteered their services. ${ }^{8}$ Despite the demotion to disarmament, many chose to join the war for a range of reasons including a sense of duty to King and Empire, to carry on familial and communal legacies of service, for sustainable employment, and even for adventure. ${ }^{9}$ Finally, the men of CC carried with them a powerful legacy of long-standing armed service to the Empire. Coloured soldiers had been enlisted by the British during the frontier wars, the South African War, and, finally, in the Great War. During this war, battalions of CC had performed exemplary service and received commendations and medals for the same, including the battle honour of Palestine 1918. As will be elaborated, this legacy of service impacted upon the self-perception of Coloured soldiers (and prisoners) in the Second World War. This chapter builds on the above stated premises and examines the experiences of CC captives by reconstructing the three dramatic phases of their ordeal: capture, period of internment and, release and repatriation.

A total of 1,032 CC soldiers were captured by German and Italian forces through the course of the war. ${ }^{10}$ During this period they endured a great amount of physical and mental exhaustion. They were made to march through the desert, called 'thirst marches', sometimes for weeks on end. ${ }^{11}$ They were starved, dehydrated and forced to work on military assignments. Treatment by German and Italian guards, as will be discussed, was racially motivated and harsh. Added to this, the prisoners in Europe also faced the challenge of being interned in lands that were completely foreign to them. The following chapter will reconstruct the experiences of these POWs and examine the impact of internment on them.

\section{INVESTIGATING CAPTIVITY}

The uniqueness of the Coloured experience of internment requires an involuted approach to this history. By analysing the external circumstance of recruitment, capture and internment, it is possible to derive and reconstruct the experiences of the CC prisoner and how they perceived and processed the trauma of war and captivity. Such an approach is inspired by Clare Makepeace's work on British POWs in Europe titled Captives of War. Makepeace's study is the first cultural history on the subject (and a critical contribution to emotional histories) that explores how POWs made sense of their experience, and the impact of captivity on their psychology and perceptions of masculinity. Despite fundamental differences between Captives of War and this chapter, Makepeace's study provides a sound methodology in its examination of embedded histories in seemingly linear narratives of war captives. 
She dissects the first-person narratives of the prisoners (in the form of diaries, letters, drawings and cartoons) by contextualising them within the circumstance of their production - that is she examines when they were written, why they were written and for whom. She further examines these narratives in conjunction to derive overarching themes of emasculation, humiliation, depression, and resistance.

The research for this chapter does not have the benefit of sizeable first-person accounts comparable to Captives of War, but by applying an analogous approach, it does attempt to reconstruct a comprehensive history of Coloured captivity in the Second World War. To further these analyses of external considerations, Karen Horn's seminal body of work on white South African POWs and Raffael Schek's compendium of studies on French African soldiers and prisoners have been used for comparison. ${ }^{12}$ The primary sources of this study are first-hand accounts of CC captives and escapees obtained from British intelligence reports and, interviews and articles published in The Cape Standard. ${ }^{13}$ These narratives have been substantiated with 'official' documents from the Department of Defence Archives in Pretoria.

The British Directorate of Military Intelligence Section 9 (MI9) was tasked with using the European Resistance networks to facilitate the return of Allied pilots and their crews shot down in Europe. The objective of the intelligence reports furnished by MI9 was to collect information on these networks. These include accounts of escapees from Italian and German POW camps and therefore contain reports of CC escapees who had been captured at Tobruk. Eleven surviving accounts are discussed here. The Cape Standard newspaper had an approximate readership of 45,000 among the Coloured, Indian and Malay communities. ${ }^{14}$ The newspaper was sympathetic to anti-segregation causes, critical of the United Party, and frequently highlighted the contributions of non-white South Africans to civil society. Therefore, it ran a robust coverage of the War that ranged from news from the front to the participation of non-white soldiers. ${ }^{15}$

A glaring shortcoming for the historian in the accounts of MI9 reports and The Cape Standard is their raison d'être. The MI9 reports were produced for the sole purpose of collection of intelligence on conditions of camps and Resistance networks. They had little concern for the experience of the individual, focusing purely on the circumstantial aspect of captivity. Similarly, The Cape Standard was concerned with the story of the "soldier" (and not the person). Their reporting focused on the collective experiences of the troops, intending to translate these experiences into a singular narrative for the front page. For the weekly publication, these were men of the Cape Corps. Thus, these first-hand accounts are incomplete as the information they narrate has been coaxed by external actors and this took away agency from the soldier who recounts it.

However, The Cape Standard articles and the MI9 reports when analysed together, reveal alternate embedded histories. For example, the most pronounced identification 
of a soldier is the insignia on the shoulder patch of the uniform. It demarcates the corps, rank and years of service of the soldier. During the Great War, the CC earned their badges in the Battle of Square Hill. Three companies of the corps participated in Allenby's Palestine Push (1917-18). Despite the limitations imposed on them by the Union, they trained and fought as one unit. However, during the Second World War, although the re-formed corps inherited the emblem, they no longer fought as one unit because of the policy of dilution. So, while Coloured soldiers replaced white non-combatants in infantry and artillery regiments, they were never formally recognised as soldiers of those regiments. This was protested on both ends. Colonel Hoy, Commander of Cape Corps, complained that the break-up of the units was causing a loss of identity and pride among CC soldiers. The Colonel's objections were overruled by the Defence Headquarters, the argument being that CC men would be proud to adopt and serve in the other regiments. However, this was never officially sanctioned. Moreover, the casualty list of non-white diluted soldiers remained separate from the casualty list of the regiments they were serving with. ${ }^{16}$

It is interesting to then note the discrepancy between this policy of dilution and the MI9 reports that systematized intelligence. While the National Archives at Kew meticulously retraced and recorded the actual unit of the Coloured soldiers (i.e. Cape Corps), the original MI9 reports identified them by the regiments they were serving with (such as the Scottish Regiment, the Border Regiment, Field regiments, and artillery divisions of the South African Corps) before their capture. This discrepancy was likely the result of the need for factual intelligence as, despite being of a different unit, they were posted and serving with the stated UDF regiments.

This discrepancy in the MI9 reports is reflective of the wartime experience of CC soldiers. Segregationist policies from the parliament and cabinet certainly outlined the terms of their service but wartime needs dictated their experience within these limits. The Union was against sending its troops beyond Africa, against arming non-whites, and intent on maintaining racial divisions on the front. In the course of the war, however, none of these policies were ever wholly or neatly executed. The experiences of Coloured soldiers from South Africa were greatly impacted by the disarray of war. By centring this study on first-hand accounts, it is possible to reconstruct a bottom-up history through the lens of the interned soldier in a chaotic circumstance.

\section{SURVIVING CAPTIVITY}

\section{From Africa to Europe}

All nine MI9 reports of the escapees have some commonalities. After their capture the soldiers were searched and stripped of all valuable and personal items including money. 
Following this they faced the first of a series of long marches. Being captured in North Africa the prisoners were forced to walk through the desert towards the Mediterranean. Newman Robinson, a white prisoner on one such thirst march, recounted how nonwhite POWs were queued last for a cup of water and half a biscuit and if the supply finished before they could receive any, the non-white POWs were simply turned away. ${ }^{17}$ This is substantiated by Private (Pte) Daniel Alexander's account who described how the POWs marched for five days to Benghazi, only being able to drink water when it rained. They had to survive on a single large biscuit shared between two men. ${ }^{18}$ They were then camped at Benghazi for two weeks. Food here was just as meagre as in the desert. A daily ration consisted of a loaf of bread between two men and a small tin of bully beef between six men. 'Pte W' [sic], who was injured when Tobruk fell, described his ordeal as a wounded captive. Along with his comrades, he was transported to Derna (a port in Libya) where he was admitted to an Italian tent hospital. "My arm was in a plaster of Paris cast. An inhuman Italian doctor simply wretched [sic] the cast off my arm; the agony was indescribable." ${ }^{19}$ Like Benghazi, the camp conditions in Derna were abysmal, "Many of us suffered from dysentery, there were flies and lice galore, we had little food, and water was scarce." 20

Next, the captives were shipped from North African ports to POW camps in Italy, Greece and the German Stalags. The journeys across the Mediterranean were treacherous as a result of intense naval warfare. ${ }^{21}$ Pte Alexander, Pte Arthur Daniels and Pte Daniel Dorman, had all been aboard Italian ships that were torpedoed. Depending on the port of disembarkation in Europe, the POWs either faced more long marches or suffocating transportations to the European camps. Pte Alexander along with thousands of marooned soldiers ended up on Greek shores. Under the vigilance of Italian guards, they walked in rain and snow, wearing only their North African desert uniforms that were grossly insufficient for the cold conditions. ${ }^{22}$ "On the first night [...] about a thousand men for shelter had about a hundred bales of straw." ${ }^{23}$ Meanwhile, Arthur Daniels and Daniel Dorman, both of whom were wounded in a different torpedo attack, were rescued by an Italian Red Cross ship and brought to Naples. They were one of the first CC men to arrive in Italy - even before the deployment of CC soldiers to the peninsula.

The non-commissioned South African POWs were divided between various transit and labour camps. There was no clear policy of segregation based on race in the camps, an aspect of captivity that CC prisoners were quick to notice, understandably so. Pte W, who had been moved by a Red Cross ship from Derna to Naples, described his experience in a hospital at Gizerta where 'nice' English POW medical staff were managing the ward. "There was no segregation in the two hospitals, white and coloured lay side by side." That the Private felt the need to single out the hospital suggests that he had previously been facing segregation. 
After his release, 'W' was transferred to Camp Lucca, where the prisoners occupied tents. Here, he described, "The cold was terrific and the mud and slush most annoying. I occupied a tent with some English-speaking and Afrikaans-speaking Springboks who were always very nice and chummy with me." Once more, by separating the identity of his white tent-mates, $\mathrm{W}$ indicates the uniqueness of this experience in Europe. Another consideration in W's narration is his referring to his white South African comrades as 'Springboks'24 (there are no accounts of non-white South African soldiers identifying themselves or each-other).

This clear need to define racial identities and highlight instances of momentary social equality (for readers of the Cape Standard ${ }^{25}$ ) points to the climacteric circumstances in the Union concerning the rights of its non-white populations. ${ }^{26}$ While, on the one hand, the POWs from Europe were acknowledging the existing social and legal separation of ethnicities within South African communities, on the other hand, they were also pointing to the possibility of coexistence under the auspices of a unifying cause (of which captivity had been a consequence).

\section{Life in Camps}

While in camps the prisoners worked in a variety of details with negligible pay. They worked as manual labourers performing jobs such as chopping wood, harvesting potatoes, digging gun emplacements, carrying munitions and bombs, and unloading supplies. They would work for as long as 10-11 hours. While prisoners in camps were, for the most part, divided on the basis of language for ease of administration, non-white soldiers, especially African soldiers, were also penned into 'non-European' camps. Here they were forced to work on aerodromes and airfields, ammunition wagons, petrol dumps and other military projects. This was perhaps the most gross violation of the Geneva Convention. ${ }^{27}$ An anonymous ex-POW of CC described his experience at one such camp,

"Only Non-Europeans were sent to Camp 85 in Italy to work on the aerodromes which continually came under Allied bombing. The camp was controlled by Germans with Italian guards. At this 'arbeitslager', ${ }^{28}$ i.e. work camp, we were forced to work. It was a case of 'Nochts arbeiten, nichts essen' [sic] i.e. no work no food. Hunger compelled several of us to do the work. A German SargentMajor used to overturn our homemade beds if we were a minute late getting up for work." 29

While several stipulations concerning health, safety and possessions of POWs (especially non-commissioned prisoners) were regularly violated, significantly white POWs were not forced to work on military projects. Moreover, while all prisoners could be employed for non-military work assignments, they had to volunteer for such work. However non-white South African captives were forced into labour as 
neither Germans nor Italians considered 'Black' POWs as regular force, and therefore the Geneva Convention was not applicable to them. ${ }^{30}$ It is also possible that 'Black' or 'African' POWs were used as they were not as actively protected by Allied commands as their white counterparts were. This was especially true for non-white South Africans as the administration of these soldiers fell entirely under the Directorate of NonEuropean Army Services (DNEAS) - an office which was not even formally part of the UDF. Such an analysis becomes more credible when compared with the situation of the French African prisoners who were also forced into dangerous war-related assignments as the Vichy government was limited in its role as a protecting power. There are also cases of white French prisoners being pushed into military assignments because of this incapability. ${ }^{31}$ As Horn's book informs, this was not the case for white South African POWs.

Of course, this is not to presume that the non-white South African POWs simply succumbed to their fate. It is possible that those who were educated or had had some form of instruction in military regulations were aware of their rights as POWs. Pte Alexander, for example, refused to work on a military labour assignment. He was punished with ten days of solitary confinement. ${ }^{32}$ In another incident, Gunner Duickers, in his account to MI9, related that he had been injured at an Italian camp during an air raid while working on an aerodrome. In retaliation, his supervisor Sgt John Colbert, a Non-Commissioned Officer of CC who was also a POW, organised a strike for ten days protesting the military nature of the work. Colbert was gaoled and work resumed. The following year, as Duickers recalled, Colbert once more complained to two Red Cross officials about the military work details being assigned to non-white South African POWs at Beauvais. While the officials agreed it was against the Geneva convention, subsequent reports of continued work at the aerodrome suggests no action was taken against it. ${ }^{33}$

However, vast number of CC POWs found themselves captive in countries they were hopelessly unfamiliar with and had no higher authorities to advocate for them. That the Red Cross officials did not press German authorities to correct such violations suggests that they may have shared their prejudice and possibly prioritised complaints of white captives. For these reasons, the Axis captors may have considered these nonwhite captives from Africa as less likely to sabotage military assignments.

In the case of CC soldiers, this theory is supported by accounts of a camp at Beauvais (a town in northern France). Several official reports and first-hand accounts from Coloured POWs pointed to the existence of a non-European camp at Beauvais that mostly held non-white South African soldiers. This POW camp, Stalag 133, was a 'Frontstalag' - one of 57 Nazi POW camps established in occupied France, originally, to imprison African soldiers of the French colonial armies. Additionally, Beauvais also had a major Luftwaffe aerodrome from where air raids were carried out by Germany during the Battle of Britain. It was therefore frequently bombed by the RAF. 
According to The Cape Standard, the Beauvais camp held nearly 400 POWs from CC and NMC units working on the aerodrome. ${ }^{34}$ Conditions here seemed more lenient as the captors allowed and provided for rugby and soccer tournaments and permitted internally-organised concerts for the amusement of the POWs. This also implies that the captives were healthy enough to engage in social activities. Indeed, "All prisoners who had been at Beauvais agreed that it was the best camp they had " 35 It is then reasonable to presume that the camp's proximity to the Allied lines on the western front and its strategic importance in aerial warfare would have incentivised the camp captors to maintain morale of their prisoners to prevent acts of sabotage and escape.

Life in most camps, however, was not as 'pleasant' as that in Beauvais. In the early days of captivity, the Red Cross, YMCA and Toc H were still establishing their presence. In a post-war report, South African Red Cross officials described how the organisation had been overwhelmed by the 'Tragedy of Tobruk'. It took months for the POW department to simply confirm the identities of the thousands of captured soldiers. This meant that little to no aid could be provided in the absence of reliable information on the prisoners. The situation of non-white POWs was particularly vulnerable as a substantial number of them were uneducated. Additionally, the organisation had to take on the responsibility of the actual correspondence between non-white prisoners and their families where relatives were illiterate. ${ }^{36}$

In the early months of internment Red Cross was not yet supplying parcels at Camp 66 in Capua (Italy) where some of the first CC prisoners were detained. Here food was so scarce the men were reduced to eating 'old bones and even grass'. ${ }^{37}$ Once conditions improved, Pte W noted, the Italian rations consisted of a 'sourish' bread that they referred to as 'catspaw', some macaroni, boiled cabbage leaves, and, on alternate days, one square inch of hard cheese. He also noted that all prisoners, irrespective of race, received the same food and treatment from the Italian guards. He further described an incident where a group of guards dumped a POW in a lavatory pit full of human excrement as punishment for attempting to steal a Red Cross parcel. ${ }^{38}$ Conditions in the Stalags were no better. Pte Dixon, who was interned at Jakobathsal (German camp near Dresden), described his time there,

"It was in the heart of winter with two feet of snow on the ground. Some of us had to sleep in draughty stables without doors and we were given two blankets each by the Germans. We managed to scrounge some grass, which we made do for a mattress. Others were not so lucky, they had to sleep outside in the bitter cold as best as they could. Six of us had to share a small loaf of stale bread about 8 inches long. We received potatoes boiled in water, but I never saw a whole potato because they were always boiled to pieces. On rare occasions we received about $1 / 2$ cubic inch of butter. The meat was blueish, and we suspected that it must have been either donkey or horse meat. It tasted neither like beef nor mutton. We Non-Europeans had an exceptionally bad time in this camp." 39 
While in the POW camps, CC soldiers unanimously attribute their survival to the Red Cross parcels they received. Despite the hardships of forced labour, Daniels and Dorman described Grotalia (camp in Italy) as the 'best camp' simply because they received food parcels from the Red Cross. ${ }^{40}$ In the Italian camps, it seems, even the captors relied on these parcels. Brown noted that the prisoners would receive only a quarter of the cigarettes assigned to them and that the Italian guards would warn them not to complain about the amount. It is reasonable to presume that the guards were responsible for the shortfall.

However, the Red Cross initiatives did have their limitations. A South African POW representative (who was himself in German captivity) described the condition of South African captives in general in an intelligence report sent to the Red Cross. He reported that the men in Italy had not received any mail for over two months, that ' $90 \%$ of parcels of cigarettes from the South African Red Cross had not arrived', that there was a severe shortage of warm clothes and boots, and that South African POWs in Italy had, on average, lost 20 kilograms in 12 months of captivity. Overall, the Allied representatives who authored the report complained that "...the British Red Cross published details about life in the Stalag which in no way correspond with the truth." 41 While the Red Cross did not explicitly make any distinctions based on race while providing aid, the aid they did provide was in most cases, just enough to allow prisoners to scrape by.

\section{Violence}

In the MI9 reports, the soldiers continually describe the violence they were subjected to at the hands of both Italians and Germans, “...the Italians treated us very badly; not much food. In Germany we were treated badly, no food.” In a collective interview Pte John April, Pte Marugoe Kgapula and Pte Aron Zvani recalled how on asking for more food the Germans would call them 'dirty English dogs' and beat them. ${ }^{42}$ Pte Hermenes Daniels further described the violence he and his comrades faced from their captors, "We were all badly mistreated and beaten with rifle butts and kicked and slapped on the face ... We worked all the time..." ${ }^{43}$ In an Italian POW camp at Pollus (Greece) Pte Joe David Brown recounted how there was no food for five days sometimes, "Many of the prisoners were ill with dysentery, and nothing was done for them." Brown was later shifted to another camp at Capua where the conditions of work were brutal. The prisoners were mercilessly beaten, especially if they became sick and could not work. ${ }^{44}$

As the war progressed, the tide began turning against the Axis powers and the treatment in camps got worse. In 1944, Pte Brown was shifted to a German Stalag in Moosburg which was, in his words, 'fit for pigs'. He was later moved to the front at Chartres (France), which was frequently under attack by American forces. 
"Whenever allied planes came over, the Germans seemed to go mad and would beat us with rifle butts for no apparent reason." ${ }^{45}$ In May of the same year, Jim McKenzie was shot and killed at the camp for complaining of being ill. ${ }^{46} \mathrm{~W}$ Harris was another CC soldier who was shot at the camp for, as the Germans claimed, being drunk. It is curious how a POW could get hold of alcohol under confinement, with little pay and even less time to spare. But even if the POW did manage to bribe someone or steal alcohol, to shoot a prisoner for drunkenness is an excess and shows how little the lives of non-white captives mattered.

These were not the only incidents of cold-blooded killings. In August 1944 the wife of Pte William Harris received a cable informing her that her husband, who had been captured at Tobruk in 1941, had been shot dead in a German camp for 'insubordination'. The Defence Department in Pretoria implied that they were investigating the circumstance of this 'insubordination' to warrant the Private's death. ${ }^{47}$ Meanwhile, at Camp 85 (Italy) Red Cross parcels of boots were being issued to the non-white prisoners when a 'native' was hit by a guard with a rifle-butt for cutting the line. The 'native' retaliated by head-butting the guard and knocked him off his heels. Fearing retribution, the captive fled and hid in the camp. After a futile attempt to find the prisoner, the infuriated guards fired at random killing an 'innocent South African prisoner', ${ }^{48}$

The violence of their captors certainly brings to fore the speculation of whether this aggression was the result of racism. In the absence of more definitive information, one way to analyse this mistreatment is to juxtapose it with the treatment of white soldiers. Brutality by German and Italian soldiers against white Allied soldiers was not uncommon. However, even a cursory reading of white POW accounts reveals that this brutality was not without 'reason'. Captors threatened their prisoners with violence as an interrogation technique, or because they (or their fellow prisoners) had attempted to escape their imprisonment, or an offending remark had been made against Germany or the German Führer. Of course, there were also those captors who were simply sociopathic and cruel, and flexed this aggression on their prisoners. Still, white POW accounts present a 'narrative' of the brutality they endured.

As a further comparison, seven soldiers of the British Parachute regiment were captured by the Germans in 1945. To interrogate the POWs, the German captors at first threatened to shoot the men, and then fed them soup doused with salt. The prisoners were then kept in the sun for seven hours without water. One of the captives, Pte Strong, was told by the Germans that the war was 'over for him' to which Strong promptly responded that the war was over for the Germans as well - following this he was severely beaten. ${ }^{49}$ A similar account was narrated by Capt. Richard Powell of the $1^{\text {st }}$ Battalion of Welsh Guards. Captured in August 1944 the Captain attempted three escapes from his prison guards. Following his second escape, he was re-captured 
in a field and severely beaten. He was then called an 'English swine' and punished with three days in a pig sty. ${ }^{50}$

For a more 'contemporary' analysis - Horn, in her book, reconstructed the experiences of white SA POWs captured in Tobruk relayed from interviews that she conducted. While Horn's interviewees do mention instances of violence, these are few and sporadic. In one instance Fred van Alphen Stahl recalled how, while on a thirst march in the desert he pointed at a jeering Italian guard and said 'two gelati tingelingling'. The furious guard was then about to shoot at the prisoners but was stopped by a soldier. In another instance, David Brokensha described how he was slapped by a guard for 'offending' him. "The slap didn't really hurt, what hurt was our youthful pride" 51 These accounts plainly reflect that, despite being goaded, captors exercised restraint as acts of violence against white captives assiduously protected by the Geneva Convention would, in all likelihood, have consequences.

Nevertheless, stories of brutality in the Second World War are endless. But it is the context of this brutality that allows for an analysis of the nuances of racialised violence. Certainly, the accounts of the seven soldiers from the British Parachute regiment are more intense than those of the Coloured soldiers captured in Tobruk. But violence on the white soldiers was carried out when it was 'provoked', whereas all Coloured POWs recount multiple instances of 'unprovoked' beatings. This treatment, of course, was not unique to CC men. In a subsequent report commissioned by DNEAS in 1947, the treatment of non-white POWs captured in North Africa and the Middle East was described as 'the worst treatment imaginable'. ${ }^{2}$ According to this damming assessment, non-European soldiers captured in North Africa were forced to work as labourers on docks, munitions, and mine clearing for long hours. They were not allowed to take shelter during bombing raids. The impact of this was most severe in Tobruk where Allied bombing was relentless post-1942. They received a packet of British army biscuits a day, little water and were kept in 'wire cages' where they were vulnerable to bombing. "Tired and weary, they are beaten and kicked by both Germans and Italians." 53

It can thus be assumed that the captors were asserting their authority over the captives, and that they did not see these captive as deserving the same treatment as their white counterparts. A more intriguing argument can then be made when this senseless cruelty is juxtaposed with the violence experienced by non-white soldiers of the French Empire. Scheck in his studies discusses the brutality of the treatment meted out to French 'colonial' soldiers who were viewed as animalistic, sub-human and violent. There are several recorded instances of 'Black massacres' wherein captured French African soldiers were indiscriminately murdered by German soldiers to exact 'vengeance'. ${ }^{54}$ However, Scheck notes that the frequency and intensity of this violence decreased as the Vichy government assumed a more active role as a Protecting Power to shield its captured non-white soldiers in Nazi camps. 
Finally, in another relevant incident, Pte April noticed an American prisoner reach into their compound for a cigarette and was unfortunately seen by a German officer. The officer stabbed the American prisoner's hand as punishment. ${ }^{55}$ This was not the only incident of brutality against Americans that CC soldiers singled out. Daniels informed that, although he and his comrades 'had it rough', the American prisoners were treated particularly badly, “...the Germans would not allow us to give them cigarettes or food from our Red Cross parcels." ${ }^{56}$ Perhaps this targeted brutality was consequence of the American advance against the Axis powers.

The violence experienced by Coloured POWs was not limited to the brutality they were forced to bear, but also the instances of cruelty that they witnessed being perpetrated on fellow captives, white and non-white. However, for the non-white prisoners this violence, although seemingly senseless, was systematically cruel. Their white captors considered non-white lives to be expendable without consequence. It can be argued that the difference in treatment meted out to white and non-white South African captives is symptomatic of the difference in protection afforded to both groups by Allied commands and neutral organisations such as Red Cross. Although the Geneva Convention of 1929 does not discriminate against soldiers based on ethnicity, the underlying assumption that non-white soldiers were not part of the 'regular forces' is not just a prejudice that the Axis captors carried, but also one that was cultivated by Allied governments and commands. After all, non-white soldiers were not paid at par with their white counterparts, could not be commissioned as officers, and, in the case of South Africans, could not bear arms. It is then fair to conclude that, on both sides of the war, non-white soldiers received the short end of the segregation stick. Despite serving the causes of liberty and democracy, these non-white prisoners were not protected by their own governments, and severely assaulted by their captors.

\section{ESCAPING CAPTIVITY}

'Escape' is perhaps one of the most dominant themes in public memory of the World Wars. Biographies of Allied POWs detailing their experiences that were subsequently converted into films constructed glamorous stories of captivity and escape. "The stories of these brave men provided a popular myth of escape, being alone in enemy territory with very limited resources, living on one's wits and returning to the arms of a loving family at home." ${ }^{58}$ As Makepeace put it, within this myth of internment, "captivity was a game for POWs, dominated by their schemes to outwit, evade and escape from their captors." ${ }^{59}$ In South Africa the most celebrated escape of a nonwhite recruit was that of Job Maseko. ${ }^{60} \mathrm{He}$ was a stretcher-bearer from the Native Military Corps, who, with the help of his comrades Andrew Mohudi, Sam Police of NMC and Koos Williams of CC, blew up a docked German cargo boat while detained in Tobruk. Despite his extraordinary bravery, Maseko was robbed of the Victoria Cross 
as he was 'African' and was instead awarded the Military Medal. His valiant feat was subsequently counted and recounted by several historians, journalists, and even in a feature documentary by Vincent Moloi titled A Pair of Boots and a Bicycle. In 1997, the South African Navy renamed a Warrior-class strike craft after him. Maseko's exploits are perhaps the most celebrated public history of participation of non-white South African soldiers.

Similarly, a most incredible feat was achieved by Pte Alexander while he was in captivity in Camp 60 in Lucca, Italy. Captured in November 1941 at Sidi Rezegh, Alexander had been a POW for almost two years when he successfully escaped from his camp. He observed the movements of the guards and sentries and carefully planned his escape by cutting the wires. Following this he proceeded to walk to Rocacastrala, a journey that took eight days. He spent the winter hiding in Rocacastrala and was joined by fifteen Americans and an Italian partisan group that was a hundred strong. Alexander served with them till they reached Allied forces. ${ }^{61}$

Gunner William Loubser successfully carried out a similar escape. Loubser had been in internment for over two years when he, like Alexander, managed to escape his camp by observing the guard shift and cutting the wires. He was near Rome at the time and was helped by civilians for a week before he was recaptured. On his second attempt, during the Italian invasion, Loubser simply 'walked out' of his camp unchallenged by the sentries. He was recaptured by the Germans in April 1944, this time Loubser was imprisoned. On his third attempt, he eluded the guards by hiding behind a pillar as the camp was being evacuated by the retreating German forces. He evaded capture and joined an Italian partisan group, serving with them until he reached a British unit at San Justina. ${ }^{62}$

However, such a linear approach of 'braving the odds' undermines the physical and psychological complexity of escape for a POW, especially a non-white captive. Prisoners, as has been explored, lived in trying conditions, suffering from malnourishment, starvation, dehydration, fatigue, untreated injuries, and diseases such as lice, fever, and dysentery. The position of CC captives was further complicated because they had not been prepared for European internment. NEAS troops were not meant to serve beyond the continent and were therefore not briefed on survival on European soil. Even a cursory reading of MI9 accounts and newspaper interviews reveals that $\mathrm{CC}$ soldiers had little information on their captors or surroundings and were unaware of their rights as POWs. They worked long hours in foreign lands with little to no information on Allied positions and were, therefore, also susceptible to demoralising rumours and Axis propaganda of Allied defeat. Harsh weather conditions further limited the 'seasons' of escape. Those who did not speak English had the additional handicap of communication. 
For CC prisoners, escaping European camps without the support of intelligence networks, little aid and a language barrier meant that a lot depended on the captive's wit and luck, and on timing. Most prisoners carried out their escape in France, presumably, because of their proximity to the front. They were all uniformly helped by French civilians who hid them, fed them, gave them civilian clothes, and aided their return to the American line. Gunner Duickers and Pte J Swartz stayed with a French family on the outskirts of Beauvais for nearly two months. Pte William Magabe, Pte Hermanes Daniels and Pte Johnny van Heerden were all hidden by civilians for twelve days before being helped to the American lines. With the threat of evacuation to German camps, several CC soldiers managed to escape from Beauvais as it was close to the American line at Chartres. ${ }^{63}$

Naturally, receiving French assistance was not an experience unique to CC soldiers. The European resistance aided Allied soldiers caught across enemy lines and hid targeted minorities like the Jewish population. What is significant is that while seeking help, these CC soldiers identified themselves as English, and not South African. While crossing the desert, Maseko and his comrades had also identified themselves as 'English' when they encountered civilian 'Arabs' ${ }^{64}$ Perhaps they called themselves English simply to identify themselves as soldiers of the Allied forces, having answered the call to serve 'King and Empire'. Or perhaps, having spent months in captivity alongside soldiers from all corners of the Empire, they now collectively saw themselves as English soldiers of the imperial army.

There are several aspects of evasion that are unique to the men of this study. Escape and evasion amongst white Allied POWs was more organised. Soldiers often received briefings on captivity, were made aware of available help should they manage to escape, and organised 'escape committees' while imprisoned. Escape itself was more organised with studies of patrolling, bribing guards for information, digging tunnels, acquiring tools and money - and finally, executing the plan. With the exception of Alexander, Loubser and Duickers - CC escapees, more often than not, chanced on opportunities of evasion, usually while being transported or evacuated. Theirs was a more 'spontaneous' and unsupported escape.

Moreover, for white Allied POWs, the challenge was to evade the secret police and military police on their tails. However, escapees generally had knowledge of Allied outposts to determine the direction of their travel to either Allied lines or neutral states. While in camp they would also be able to acquire information on trains, ports, and details of civilians helping escapees. Similarly, non-white South African POWs who carried out successful escapes from North African POW camps had already served in the region and thus had a fair amount of information on the geography and movement of troops. Thus, despite facing daunting marches through the desert that could last from five days to a month, numerous daring attempts to escape, especially during air raids, were made. ${ }^{65} \mathrm{CC}$ escapees in Europe, contrarily, had little information 
on Allied lines and relied heavily on the goodwill of civilians to hide, help and guide them to American and British posts. This lack of information would have discouraged many from attempting to escape - the dilemma remained, escape and go where? One example of this comes from Pte W,

"After the capitulation of Italy the Jerries [Germans] came with six truck-loads of men armed with machine- and tommy-guns. The colonel and the captain of Luca Camp were shot at the camp gates. We prisoners who thought that we would receive the same treatment jumped over the barbed wires. The Germans did not open fire on us but called us back and took us to a German camp near Dresden." ${ }^{66}$

Despite having the opportunity to escape, the prisoners chose to 'return' to captivity as a way of survival. Another example is Pte William Magabe's 'failed' escape. Magabe's first escape was from an Italian camp. He evaded capture for three months, hiding in the countryside with the aid of Italian civilians, until he was caught. Even though Magabe eluded his captors for a prolonged period, that he was unable to make it out of enemy territory suggests the lack of information he had. Nevertheless, his second (and successful) attempt was in France where he managed to cross over to American lines.

\title{
REPATRIATION
}

The road to liberation was long for CC captives. Their first experience of Axis defeat was the invasion of the Italian peninsula. As Allied forces made gains, Germans began evacuating POW camps in the region. Prisoners were transported by train, trucks and on foot. Pte D who, along with his comrades, was transported from Lucca to Germany, described the abhorrent journey,

\begin{abstract}
"We were issued with rations for seven days, put in cattle trucks which were nailed shut and covered with many strands of barbed wire. There was no chance of escaping. Two pails were given to us to be used as lavatories and by the time we reached the Brenner Pass, the stench was so awful and flies and fleas covered our bodies." 67
\end{abstract}

Several Coloured POWs were eventually transferred from Germany to labour camps in France such as Beauvais. As the American line began pressing on the French front, CC prisoners became part of the long taxing marches to the heart of the Third Reich. As has been discussed, some POWs managed to escape during these evacuations and reported to American lines. The existing sources are silent on how the POWs reacted to Germany's unconditional surrender. One can imagine it must have made homecoming a sweet reality. 
As the Allied advance progressed rapidly in 1945, they liberated several labour and POW camps. Freed South African POWs were moved from the continent to ports in England where they were received by UK authorities and subsequently transferred to UDF reception camps being managed by the South Africa House in London. The reception camps were divided between 'European' and 'non-European' soldiers. At the reception camps, the former POWs received medical attention, were issued new clothes and pay-books with pay, and transferred to segregated rest camps. All 'European' ex-POWs were granted 30 days of leave for recuperation; 'Non-European' ex-POWs were allowed no leave during their stay (possibly to prevent them from mixing with the local populace) and instead 'outings, picnics and tours' were arranged for them. ${ }^{68}$

Subsequently, soldiers were shipped across the Atlantic and down to the ports of Cape Town and Durban where they were welcomed by cheering crowds. On 13th February 1945, few months before the end of hostilities, 700 released CC and NMC prisoners on liners accompanied by two battleships were bought into Durban. There they were welcomed by Col Stubbs, head of the DNEAS. The Colonel greeted his men with a short speech that he repeated in English, Afrikaans, Sesotho and Xhosa, "I thank God that you have all been spared and that you have had a safe journey across the seas. Your capture and the welfare of your families have been a great concern to me but with the help of the Almighty you have all returned, and I hope that you will all be fully restored to health, ready to take up your positions where you left off when you were captured." ${ }^{69}$ The soldiers were then given refreshments and transported by train to Pretoria where 'plans were elaborate'. They were served with buns, minerals, ginger beer, cigarettes, and music was provided by Directorate Film Vans. ${ }^{70}$

It is difficult to imagine how these soldiers would have perceived their return, carrying the burdens of their traumatic captivity while being reunited with family and friends who they had probably lost hope of seeing again. They must have been relieved yet traumatised and scarred, mentally and physically, from their experience of captivity. AS Mopeli-Paulus, son of a Mosotho Chief who had joined CC 'by accident', would later describe his return to South Africa from a successful campaign at El Alamein, "At last we landed. In the midst of our welcome we remembered, this was a country of thorns for us." 71

\section{THE TRAUMA OF INTERNMENT}

White Allied POWs, as Makepeace notes, documented their experience in three forms of records: (i) correspondence, (ii) log books issued by the YMCA, (iii) diaries. Through these narratives Makepeace was able to reconstruct a history of how prisoners experienced captivity as it occurred. "Diaries, letters and logbooks were written as the experience unfolded, at a series of moments, over a period of time, whilst these men 
were in the midst of both a shifting war situation and changing personal relationships, without an awareness of how the war would finally end."72 For the men of this study, it is unclear whether they received logbooks or diaries to record their experiences. If they did, these sources have certainly not survived in archives. However, it is likely they were not issued any writing material except stationery for letters and postcards. This was perhaps because most of the non-white Allied soldiers were illiterate as well as working exhaustive gruelling hours. Furthermore, scholarly works on other nonwhite Allied histories also majorly source their first-person narratives from letters, postcards, second-hand accounts, and oral testimonies. There is certainly an underlying racialised element here of the assumed unimportance of non-white narratives. Where all white soldiers within Allied forces were at least afforded the opportunity to record their stories, it seems the assumption was that non-white stories did not merit a similar recognition. As for correspondence, while it is highly plausible that letters and postcards did make it across the Atlantic to the relatives of $\mathrm{POWs}^{73}$, it is almost futile to attempt to trace these as, unlike in Britain and USA ${ }^{74}$, no organised efforts were launched in South Africa to collect and document such sources. Thus, for soldiers of $\mathrm{CC}$, to imagine 'an insight into how prisoners of war experienced captivity', one must rely on the deductive and embedded histories in existing sources.

A key point of inquiry for Makepeace was perceptions of masculinity among POWs. She examined the impact of surrender, disarmament, propaganda and mistreatment by camp officials on the psyche of a POW and how they did (or did not) cope with this 'emasculation' during and after the war. A crucial component of coping with this emasculation, as Makepeace and Horn observed in their works, was their perception of the Italian and German guards. By viewing the Italian soldiers as less than themselves, and the Germans as fighting for a 'losing' side, the POWs were able to cope with the 'shame' of disarmament and their inability to fight on the front as their noncaptured comrades were doing. As Horn described, the position of Afrikaner prisoners was more complicated than that of their English counterparts. However, uniformly, escape formed a key part of their defiance of captivity, as did attempts at sabotage, and provocation of guards and sentries against the propaganda of Allied defeat.

Horn expounded these emotions of betrayal and defeat amongst the white South African forces in Tobruk. In an interview with Horn, Fred van Alphen Stahl, who had been taken prisoner, described his experience as, "this is the end', because while the thought of losing one's life was a valorous undertaking, the thought of being a prisoner of war was simply not "imagined'." 75 Furthermore, the shock of the fall of Tobruk stemmed heavily from the lack of a confrontation as seasoned fighting men did not receive orders to defend their posts. "I had not for a moment thought we would surrender," recounted Lieutenant Goldman, "It seemed fantastic. We had not fired a shot." 
For CC prisoners, disarmament was not related to emasculation or the feeling of 'shame'. As the soldiers had already been disarmed by their own government, for them the right to bear arms was more closely related to their political rights as 'firstclass' citizens of the Union of South Africa. The Coloured community, as the Cape Corps Association assured General Smuts, had already proven their fighting worth in previous wars and were prepared to provide young men en masse of the same calibre for this war. ${ }^{77}$ It was not the ability of the men but the politics of the Union that was obstructing them. It is thus reasonable to deduce that 'surrender' and 'disarmament' for the Cape Corps men did not necessarily 'tarnish' their 'sense of honour'. ${ }^{78}$

This argument is further supported through an examination of the articles on POWs published in The Cape Standard. There are certain characteristics of the interviews conducted by the weekly. For one, there was no rule of thumb on the identity of soldiers. While some ex-prisoners were forthcoming with their name and addresses (perhaps allowing other members of the community to contact them), others preferred to refer themselves simply with their initials (such as 'Pte W', 'Pte A'). This could be a result of their desire to protect the privacy of their experience. Considering that within the article there was a variation in the format of names, and that the accounts of the ex-POWs were extensive - it is unlikely that the lack of details about the interviewees was a consequence of negligence by the journalist. Each interview in the article varied in size and this suggests that the writer eliminated the commonalities between them and chose to instead focus on the 'unique' aspects of the stories. The interviews also seem to have been led by questions on life in European campaigns, questions about segregation, treatment at the hands of Germans, and perhaps even their experiences with other white nationalities. In compiling these stories, the published piece presents a narrative of loyalty, of physical and mental capability, of service, and of hardships suffered by the Coloured soldier for King and Empire. The section on the Beauvais camp is perhaps the most intriguing addition amongst the interviews. This was likely due to the number of Coloured POWs in Beauvais (and therefore this was a common topic for discussion), or perhaps an ode to the spirit of the soldiers who had spent long years in captivity.

Nevertheless, the focus on internment in Europe (and not in other theatres of war such as North and East Africa, and the Middle East) also demonstrates the importance of 'Coloured' soldiers having participated, even in the capacity of a captive, in the 'white man's war' on the white man's land. The true extent of the violence of the Nazi camps was perhaps felt most acutely by the POWs in their sensitivity to the plight of European civilians in labour camps. Despite having faced trying conditions himself, Pte A recounted, "It nearly broke my heart at Compiègne to see French civilians including many cripples being sent to the labour camps in Germany." For Pte Dixon, his worst experience was in a German camp where he resided with "thousands of Russian male 
and female prisoners of war." No account in the articles reiterates such empathy for other non-white nationalities. The singling out of these experiences suggests that while the Coloured prisoners did not expect fair treatment from their white captives, the violence they witnessed against white civilians certainly affected them.

In the introduction to the seminal work Africa in World War Two, Timothy Parsons observed, "The circumstances under which a man becomes a particular kind of colonial soldier were usually the primary factor in determining how he viewed the nature of his service and behaved in combat." 79 Perhaps this definition can be furthered for CC prisoners - the circumstances under which colonial soldiers were interned were the primary factor in determining their survival and impact of captivity on the soldiers.

As discussed above, the physical strain of being a non-white captive of war was enormous. Thus, it is difficult to fathom the mental strain it would have had on the POWs. The surviving sources do not allow for an insight into the psychology of Coloured prisoners or the extent of PTSD among them. However, it can be deduced that prolonged captivity in foreign lands, exhaustive hours of work, unfavourable weather, appalling food and living conditions, must have depressed and demoralised the POWs to a point of defeatism and hopelessness. An anonymous CC captive described how susceptible he and his comrades had become to Axis propaganda, "When the Italians told us of the Italian armistice we did not believe them, because they had so often told us lies e.g. they told us Alexandria had fallen." ${ }^{80}$ As a comparison, the white captives in Makepeace and Horn's studies actively resisted accepting any form of 'news' given by their captors on Allied defeat.

The same anonymous soldier (most likely suffering from severe PTSD), further detailed the anxiety he felt,

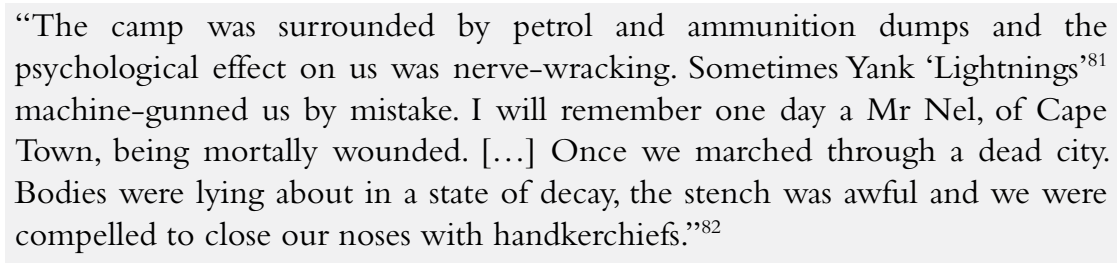

The anonymous ex-POW would not have been alone in his trauma. The inability to further expound the mental anguish of these POWs is the most glaring and regrettable limitation of this piece. However, the following is a poem sent to the Cape Standard written by a CC captive in the Middle East. This will, perhaps, more effectively illuminate the psychological ordeals of war and captivity, 


\author{
Barren wastes of scrub and sand, \\ Dry unfertile desert land, \\ Spiked wire on every hand, \\ A hapless post of hungry men, \\ Crowded like rats in cage and pen, \\ Shut off it seems from human ken, \\ Ill clad unkempt and underfed, \\ Trading your watches, rings for bread, \\ A chilly concrete floor for bed, \\ Queuing long hours in the blistering heat, \\ Receiving a morsel of bread and meat, \\ Glad if even scraps to eat, \\ Striving to keep alive your hope, \\ Feeling at times its beyond your scope, \\ Drugging yourself with rumours as dope, \\ Setting new values on trivial things, \\ The smell of a flower, a bird that sings, \\ The beauty and grace of a butterfly's wings, \\ Bullied and driven like flocks of sheep, \\ Treated as dirt from dawn to sleep, \\ Hearts being filled with a hatred deep, \\ Cut off from news of the outside world, \\ Sifting the truth in the taunts that are hurled, \\ Silently keeping the flag unfurled. ${ }^{83}$
}

\title{
CONCLUSION
}

War is ugly, and captivity is brutal. Stories of captured Cape Corps soldiers underscore this grim reality. But they also bring to fore the additional tragedy of internment as a non-white prisoner. 'Coloured' soldiers were subjected to unprovoked violence, worked long gruelling hours, were not protected de facto by the Geneva Convention or the Allied commands and governments, were unfairly uninformed about their circumstance and had no prospects of returning home. This further pronounced the mental and physical trauma of starvation, exhaustion, and despondence. One can only speculate the will of the CC captives to survive this unsparing internment. However, this disarray of captivity in Europe also allowed for discordant experiences as captives witnessed the dreadful treatment suffered by persecuted white civilians, the aid escaped ex-prisoners received from European civilians, and other noted incidents. It is curious to think how these experiences must have impacted them. Did these encounters influence them as their homeland entered its most brutal phase of segregation? How severe was their mental trauma? Did they survive it? No sources have yet been uncovered that can shed light on the war CC ex-prisoners carried home with them.

In the introduction of Captives of War, Makespace identified a quandary in the interpretation of narratives of war. Makepeace's grandfather, himself a veteran of the Second World War and an ex-POW, read and commented on drafts of her book. 
His observations ranged from shock on the number of parcels other POWs received to his ignorance about entertainments in captivity. More importantly, the act of commenting itself added an analytical depth to her understanding of the research she had conducted. “... His [Makepeace's grandfather] response[s] made me acutely aware from early on, that this history of captivity could never presume to be representative of the experiences of all prisoners of war. Nor would I claim it be representative of those prisoners of war, whose narratives I have read." ${ }^{44}$

Unlike Makepeace's thorough book, this is but a short chapter in a large compendium and it has been built on even briefer accounts spread between time and space to provide a coherent portrait of this shadowed history of POWs. This study does not claim to represent the histories of all captive Coloured soldiers. However, by piecing these sources spread unfavourably between dispersed archives, it is hoped that a window, if limited in view, into the story of the Coloured POW has been opened. 


\section{Endnotes}

1 The term "Coloured" has been used strictly in its historical context to characterise soldiers from "mixed-race" communities who also self-identified with the nomenclature.

2 The battles for Sidi Rezegh and Tobruk were part of a larger campaign in North Africa between General Erwin Rommel's German and Italian troops and the British Imperial forces with the objective taking control of the Suez Canal. Although Sidi Rezegh was not a key battle in the overall campaign, South African bravery in the battle resulted in heavy losses of tanks for the Germans despite their victory. Tobruk, on the other hand, was a key fortress that held large supplies for the Allied forces, including arms and ammunitions, and the Eight Army was deployed there in substantial numbers. The loss of the fortress was a major military and political setback for then Prime Ministers Winston Churchill and Jan Smuts. During the campaign, the Allied forces suffered 35,000 casualties at Tobruk alone.

3 While Japanese POWs have been included in larger narratives of the war, there are very few dedicated studies detailing their fate. These include chapters and journal articles by Arnold Krammer, Clifford Kinvig, Kent Fedorowich, Charlotte Carr-Greg, SI Kuznetsov, and a gripping first-person account by Mitsugu Sakihara. Over half million Japanese POWs were held by the Red Army alone. The mistreatment of Japanese captives was racially motivated, and their Allied captors were slow to repatriate them at the end of the war. Despite the important contributions by the listed scholars, several large gaps remain in the histories of Japanese POWs.

4 B Nasson, A Jacana Pocket History of South Africa at War 1939-45 (Johannesburg: Jacana, 2012), pp 20-22.

5 BP Willan, Albert Grundlingh, Bill Nasson, John Keene, Louis Grundlingh, Suryakanthie Chetty, Neil Orpen, K. W. Grundy, Mirjana Roth, Ian Gleeson, Neil Roos, and Jennifer Crwys-Williams have all filled niche gaps in the literature. And while Nasson, Keene, Horn, Orpen, and Gleeson have referenced non-white South African POWs in their studies, these histories are brief and subordinated to larger narratives of the war.

6 This chapter is part of my doctoral project (under Dr Joanna Lewis at LSE) on the service of Cape Corps and Indian and Malay Corps during the Second World War. My dissertation seeks to analyse the impact of the Empire and the South African Union's racial policies and politics on the service of these units, the 'lived experiences' of soldiers in these units, treatment of soldiers post-war, impact of their service on their communities, and commemoration of their service.

7 The official policy from London on recruitment was for the creation of a 'voluntary' force. This idea of the British rallying the largest voluntary force continued post-war. However, several historians have since debunked this myth by examining the unofficial practices by local governments in the colonies to increase the number of recruits and meet the demands of Whitehall. From press-ganging young men in Kenya to the lack of government intervention as mass exports created record-high inflation and dire food scarcity in India, forcing many to enlist to support their families; various tactics were employed off-the-record to create this largest 'voluntary' force. See T Parsons, 'The Military Experiences of Ordinary Africans in World War II'. In: JA Byfield, CA Brown, T Parsons \& AA Sikainga, eds., Africa and World War II (New York: Cambridge University Press, 2015);Y. Khan, The Raj At War: A People's History Of India's Second World War (London:Vintage Publishing, 2015); KC Yadav, 'Army Recruitment in Punjab, 1846-1913: An Evolutionary Study', Journal of the United Service Institution of India, vol. CXLVI, no. 605 (2016); J. Lewis, Empire State-Building: War and Welfare in Kenya, 1925-52 (Ohio: Ohio University Press, 2000). 
8 When war broke out in 1939, South Africa, despite being a dominion of the British Empire, did not immediately declare its loyalty to the Crown. The parliament only narrowly approved participation in the war on Smut's assurance that there would be no conscription of anyone, officially and unofficially. Thus, handicapped by their own divided prejudiced politics, they could only enlist volunteers.

9 Primary sources collected for my doctoral thesis highlight the many motivations of young men from Coloured, Indian and Malay communities who enlisted. These sources present an alternate history that opposes the notion of enlistment born out of economic need. For example, in 1942, an article published in The Scotsman, a liberal daily, critiqued the Union government for wasting the potential of young, educated non-white men who were enlisting in the South African forces despite being forced to work in auxiliary capacities. These men had better economic opportunities outside of the defence forces but were responding to the call of loyalty to King and Empire. British Newspaper Archives (BNA): 'War Effort in South Africa: Magnificent Within Limits Colour Bar a Weakness', The Scotsman, 24 October 1942.

10 JE Loraine-Grews, 'Union Defence Forces: Statistics of the Wounded and Prisoners of War during the Second World War 1939-1945', Militaria, vol. 15, no. 1 (1985), p 62.

11 IB Greeff, 'South African Prisoners of War in the Long Marches 1944-1945', Military History Journal, vol. 8, no. 6 (1991).

12 K Horn, "Stalag Happy": South African Prisoners of War during World War Two (1939-1945) and their Experience and Use of Humour', South African Historical Journal, vol. 63 (2011), pp 537-552. Horn, In Enemy Hands: South Africa's POWs in World War II (Jeppestown: Jonathan Ball, 2015). Horn, “"A sudden sickening sensation”: South African prisoner-of-war experience on board the San Sebastian, December 1941', Historia, vol. 63, no. 1 (2018), pp 112-129. R Scheck, 'French African Soldiers in German POW Camps, 1940-1945’ In: JA Byfield, CA Brown, T Parsons \& AA Sikainga, eds., Africa and World War II (New York: Cambridge University Press, 2015); Scheck, French Colonial Soldiers in German Captivity During World War II (New York: Cambridge University Press, 2014)

13 A commercial weekly newspaper published in Cape Town by an Indian firm, Prudential.

14 G Lewis, Between the wire and the wall: a history of South African 'Coloured' politics (Cape Town: David Philip, 1987), p 184.

15 Under then Editor, George Manuel, the weekly also coordinated with the Directorate of Non-European Army Services (DNEAS) for recruitment and press campaigns, sourcing several articles and photographs from the Directorate. These were also distributed amongst soldiers in transit camps within the Union. It is reasonable to assume that the Standard's cooperation and aid in the press campaigns, as well as the popularity of their war reporting would have enabled their access to returning soldiers (those on leave and repatriated ex-POWs) for interviews. DNEAS, Box 36, 8/21, Cape Corps: Propaganda and Press Matters, Department of Defence (DOD) Archives, Pretoria.

LA Crook, 'Non-White Personnel in the SA Artillery: 1939-45, and Today', Militaria, vol. 24 , no. 2 (1994), p 20.

17 Horn, In Enemy Hands, p 51

18 'Many Ex-Prisoners Return', The Cape Standard, 19 Jun 1945, Microfilm BZA 89/8397, University of Cape Town Special Collections (UCT).

'Nerve-Racking Experience', The Cape Standard, 15 May 1945, Microfilm BZA 89/8397, UCT.

20 'Nerve-Racking Experience', The Cape Standard, 15 May 1945, Microfilm BZA 89/8397, UCT. 
21 The Italian Regina Marina lost a total of 83 warships and 83 submarines in the Mediterranean and the Red Sea between 1940-43.

22 Horn, "A sudden sickening sensation”, p 124.

'Many Ex-Prisoners Return', The Cape Standard, 19 Jun 1945, Microfilm BZA 89/8397, UCT.

24 War propaganda directed at young white South African men focused on enlistment by tapping into aspects of masculinity and settler identity, and was intricately related to sports and physical activity, i.e. 'Springbok Army of Sportsmen'. However, these concepts were based on exclusion of non-white men relating that the fighting feature was a tradition of white regiments. S Chetty, 'All the News that's Fit to Print:The Print Media of the Second World War and its Portrayal of the Gendered and Racial Identities of the War's Participants', South African Historical Journal, vol. 54, no. 1 (2005), pp 30-53. S Chetty, 'Imagining National Unity: South African Propaganda Efforts during Second World War', Kronos: South African Histories, 38 Special Issue (2012), pp 106-130.

For whom "W", Alexander, Arthur Daniels and others were recounting their experiences briefly.

By 1945, the Union was experiencing a steep rise in segregationist politics. A consequence of this was the creation of a 'Coloured Advisory Council' that aimed to separate the "affairs" of the Coloured population from that of the White population. This was to function on a similar tangent as the Native Affairs Department.

27 Article 31 of the 1929 Geneva Convention states, 'Work done by prisoners of war shall have no direct connection with the operations of the war. In particular, it is forbidden to employ prisoners in the manufacture or transport of arms or munitions of any kind, or on the transport of material destined for combatant units [emphasis added].'

These were forced labour camps run by Nazis for the war industry.

'Nerve-Racking Experience', The Cape Standard, 15 May 1945, Microfilm BZA 89/8397, UCT.

Horn, In Enemy Hands, p 57.

Scheck, French Colonial Soldiers, p 182 - 192.

'Many Ex-Prisoners Return', The Cape Standard, 19 Jun 1945, Microfilm BZA 89/8397, UCT.

WO 373/63/177, The National Archives of the United Kingdom, Kew (TNA).

As has been previously seen in the case of Sgt Colbert, it was unlikely that there would be any intervention on behalf of these POWs to prevent them from working on the aerodrome, making them the ideal labour force.

'Many Ex-Prisoners Return', The Cape Standard, 19 Jun 1945, Microfilm BZA 89/8397, UCT.

J Hasted, “The South African Red Cross in War 1939 - 1945”, pp 91-96, UWH, Box 25, DOD Archives.

'Many Ex-Prisoners Return', The Cape Standard, 19 Jun 1945, Microfilm BZA 89/8397, UCT.

As Makepeace noted, this was a common punishment for theft and insubordination: the objective being to humiliate and dehumanise the captive. 89/8397, UCT. 
40 Provided by the International Committee of the Red Cross, the Red Cross parcels consisted of food, tobacco and items of personal hygiene for POWs during the World Wars. Distribution of this was in accordance with the Geneva convention and helped POWs survive.

41 Reports on Visits POWs and Internees, 30 Oct 1943, CGS, Box 189, file 40/28, DOD Archives.

42 Natives were also recognised as 'English' by Arabs in the desert (historical survey of NE), WO 208/3349/550, TNA.

43 WO 208/3349/547, TNA.

44 WO 208/3350/1181, TNA.

45 WO 208/3350/1181, TNA.

46 WO 208/3350/1181, TNA.

47 'Prisoner of War', The Cape Standard, 1 Aug 1944, Microfilm BZA 89/8397, UCT.

48 'Nerve-Racking Experience', The Cape Standard, 15 May 1945, Microfilm BZA 89/8397, UCT.

WO 208/3350/1084, TNA.

50 WO 208/3350/1045, TNA.

51 Horn, In Enemy Hands, pp 51, 56.

52 Capt JC Knoetze, “Historical Survey of Non-European Army Services”, UWH, Box 158, Narep Unfo 12, O(1) 21/47, DOD Archives.

Axis cruelty to native prisoners, 11 Sep 1942, UWH, Box 130, Narep ME 4, DOD Archives.

Scheck, French Colonial Soldiers, pp 32-40, 104-108.

55 WO 208/3349/550, TNA.

56 WO 208/3349/547, TNA.

57 Some cult classics based on true accounts of escape include The Great Escape (1963),

The Wooden Horse (1950), Stalag 17 (1953), Escape from Sobibor (1987), The Elusive Corporal (1962), The One that Got Away (1957).

58 S Tyas, 'Escapes of Allied Prisoners of War and Forced Labourers from German Captivity'. In: MN Soleim, ed., Prisoners of War and Forced Labour: Histories of War and Occupation (Newcastle upon Tyne: Cambridge Scholars Publishing, 2010), p 180.

59 C Makepeace, Captives of War: British Prisoners of War in Europe in the Second World War (Cambridge: Cambridge University Press, 2017), p 6.

60 Also spelled 'Masego'.

61 WO 373/64/862, TNA.

62 WO 373/64/616, TNA.

63 WO 373/63/177, TNA.

64 Historical Record of Non-European Army Services, UWH, Box 158, Narep Unfo 12, DOD Archives.

65 Historical Record of Non-European Army Services, UWH, Box 158, Narep Unfo 12, DOD Archives.

66 'Nerve-Racking Experience', The Cape Standard, 15 May 1945, Microfilm BZA 89/8397, UCT.

67 'Nerve-Racking Experience', The Cape Standard, 15 May 1945, Microfilm BZA 89/8397, UCT. 
68 DOD: CGS WAR, Box 189, 40/31, POW Welfare Committee.

69 'Prisoners of War Return', The Cape Standard, 13 Feb 1945, Microfilm BZA 89/8397, UCT.

70 'Prisoners of War Return', The Cape Standard, 13 Feb 1945, Microfilm BZA 89/8397, UCT.

71 AS Mopeli-Paulus, The World and the Cattle (Johannesburg: Penguin, 2008), p 98.

72 Makepeace, Captives of War, $\mathrm{p} 22$.

73 Alongside lists of captives published in The Cape Standard, information was also provided for next-of-kin to contact Red Cross Society offices. 'Prisoners of War, The Cape Standard, 2 Mar 1944, Microfilm BZA 89/8397, UCT.

74 'WW2 People's War' project by BBC histories to document oral histories, the War Memories project archived by the British Library, projects by the National World War II Museum in New Orleans.

75 Horn, In Enemy Hands, p 39.

76 Horn, In Enemy Hands, p 40.

77 'Fund for Purchase of Spitfires', The Evening Telegraph, 13 Jun 1940, BL_0000563_19400613_081_0009, BNA.

78 Horn, In Enemy Hands, p 42.

79 Parsons, 'The Military Experiences of Ordinary Africans in World War II', p 12.

80 'Nerve-Racking Experience', The Cape Standard, 15 May 1945, Microfilm BZA 89/8397, UCT.

81 The American fighter aircraft 'Lockheed P-38 Lightning'.

82 'Nerve-Racking Experience', The Cape Standard, 15 May 1945, Microfilm BZA 89/8397, UCT.

83 Poem, The Cape Standard, 19 Jun 1945, Microfilm BZA 89/8397, UCT.

84 Makepeace, Captives of War, p 28. 